\title{
MODEL ROLE PLAYING, SIKAP EMPATI DAN PEMBELAJARAN TEMATIK TERPADU DI SEKOLAH DASAR
}

\author{
Akhmad Badrul Lubis ${ }^{1}$, Firman ${ }^{2}$ \\ ${ }^{1}$ Jurusan Pendididkan Dasar dan Jurusan Bimbingan Konseling \\ Fakultas Ilmu Pendidikan Uiversitas Negeri Padang
}

Email: firman@konselor.org

\begin{abstract}
Abstrak
Artikel ini membahas tentang pengunaan model Role Playing untuk membentuk sikap empati dalam pembelajaran tematik terpadu di sekolah dasar, melalui kajian teori yang dilakukan maka diperoleh kesimpulan - kesimpulan yang dapat di jadikan rujukan dalam penerapan model Role Playing pada tema organ gerak manusia dan hewan di sekolah dasar, berdasarkan kajian teori yang dilakukan secara mendasar oleh penulis maka diperoleh kesimpulan bahwa, dengan menggunakan model Role Playing maka dapat membentuk sikap emati siswa yang juga berdampak secara positif pada pembelajaran tematik terpadu yang dilaksanakan. Karena dalam model Role Playing memberikan kesempatan kepada siswa untuk terlibat langsung dalam melaksanakan, menemukan, dan menyimpulkan pembelajaran yang dilaksanakan.
\end{abstract}

Kata-kata kunci : Model Role Playing, Sikap empati, Pembelajaran tematik terpadu, Sekolah dasar.

\section{PENDAHULUAN}

Terjadinya globalisasi yang bergitu menyenangkan dengan teman-temannya, cepat membuat banyak negara melakukan baik itu teman sekelas maupun teman beda perubahan pada dunia pendidikannya, karena kelas, dan belajar merupakan salah satu keberhasilan suatu bangsa dalam bagian utama dari beberapa bagian yang membangun pendidikan menjadi barometer memberikan pengaruh dan terlibat langung tingkat kemajuan bangsa yang bersangkutan (Sumarto, 2002)

Perubahan yang nyata dilakukan dengan memberikan proses belajar di sekolah yang sesuai dengan perkembangan siswa, karena Jeanne Ellis Ormrod (dalam Melka, Ahmad, Firman, Syukur, Sukmawati, \& Gusri, 2017) menjelaskan bahwa sekolah sebagai suatu lingkungan sosial, dimana para siswa menjalin hubungan sosial yang dalam pembentukan pribadi dan sikap individu (Firman, 2018).

\section{Hakikat Belajar dan Pembelajaran}

Ada beberapa pendapat para ahli yang menyatakan tentang pengertian belajar, diantaranya menurut Ahmad sabri (2007) menyatakan bahwa "Belajar adalah proses perubahan perilaku berkat pengalaman dan pelatihan", senada dengan pendapat itu menurut Suryabrata (dalam Uno, B. Hamzah 
dan Mohammad, 2015), menyatakan bahwa "Belajar adalah suatu proses yang menghasilkan perubahan perilaku yang dilakukan dengan sengaja untuk memperoleh pengetahuan, kecakapan, dan pengalaman baru ke arah yang lebih baik". Sedangkan menurut Dimyati dan Mujiono (2013:7), menyatakan bahwa "Belajar merupakan tindakan dan perilaku siswa yang kompleks".

Berdasarkan beberapa pendapat tersebut, maka belajar dapat diartikan sebagai proses perubahan perilaku yang diakibatkan oleh kegiatan yang dilakukan oleh seseorang berdasarkan pengalaman selama melakukan proses kegiatan tersebut, sehingga terjadilah perubahan tingkah laku, baik dalam bentuk sikap, pengetahuan dan keterampilan.

Peninjauan dan perubahan yang dilakukan (dalam pembelajaran) dilakukan oleh pemerintah untuk mengantisipasi perkembangan zaman yang begitu pesat (Trianto, 2007). Dilaksanakan dengan melakukan perubahan pada KTSP (kurikulum tingkat satuan pendidikan) yang mengunakan pendekaran konvensional, dilakukan perubahan menjadi Kurikulum 2013 (K13) yang menggunakan pendekatan saintifik (Rusmawan, 2015).

Kurikulum 2013 adalah kurikulum berbasis pada pembelajaran tematik terintegrasi, yaitu pendekatan pembelajaran yang mengintegrasikan berbagai kompetensi dari berbagai mata pelajaran ke dalam berbagai tema (Afifurrahman, 2015). Kurikulum ini menekankan kompetensi peserta didik pada 4 ranah, yaitu sikap spiritual, sikap sosial, pengetahuan, dan keterampilan (Novianto \& Mustadi, 2015). Menghasilkan perubahan tingkah laku dan kemampuan, yang lebih baik serta sesuai dengan peserta didik untuk menghadapi tantangan masa depan (Rusmawan, 2015).

Materi yang disajikan dalam pembelajaran tematik disusun berdasarkan tema tertentu dan tidak lagi terfokus pada mata pelajaran (Dyah Worowirastri E., Ima Wahyu P.U, 2018). Hal tersebut senada dengan pendapat Randle (2010: 85) menambahkan "Integrated Thematic Instruction-based curricula stresses the integration of all disciplines to present students with learning experiences that are based on real-world application and structured to encourage higher-order learning". Artinya, bahwa pembelajaran tematik integratif menekankan pada pengintegrasian semua disiplin ilmu dengan pengalaman belajar yang berbasis pada pengalaman peserta didik dan struktur dunia nyata, sehingga mendorong pembelajaran menjadi lebih bermakna.

Penerapan Kurikulum 2013 diharapkan dapat menghasilkan peserta didik yang berkarakter, berilmu pengetahuan, dan memiliki keterampilan. hal tersebut sesuai dengan arti kurikulum 2013, yaitu kurikulum yang dapat menghasilkan insan Indonesia 
yang produktif, kreatif, inovatif, efektif melalui penguatan sikap, keterampilan, dan pengetahuan yang terintegrasi (Kemendikbud, 2013). Terutama sekolah dasar sebagai lembaga formal awal yang sangat berpengaruh pada pembentukan dan pendayagunaan potensi yang ada pada perkembangan setiap siswa.

Kurikulum 2013 menunjukan, bahwa guru kelas di SD memegang semua mata pelajaran, kecuali agama dan olah raga (Warsiti, 2003), sehingga penerapan prinsip kurikulum 2013 tidak terlepas dari guru sebagai pelaksana dilapangan yang akan menjadi salah satu penentu keberhasilan.

Permendikbut Nomor 65 Tahun 2013 Mengenai Standar Pendidikan Dasar dan Menengah yang menyebutkan bahwa Sesuai dengan standar kompetensi lulusan dan standar isi, maka prinsip pembelajaran yang digunakan dari pembelajaran parsial menuju pembelajaran terpadu", Pembelajaran kurikulum 2013 harus dilakukan dengan pembelajaran tematik terpadu, salah satu yang menjadi perhatian penulis dalam penerapan kurikulum 2013 adalah pelaksanaan pembelajaran IPA, yang merupakan pembelajaran yang berhubungan langsung dengan kehidupan alam sekitar peserta didik.

IPA merupakan suatu ilmu yang bersifat objektif yang mempelajari tentang alam sekitar beserta isinya, peristiwa dan gejalagejala yang muncul di alam berdasarkan fakta, konsep, prinsip dan hukum yang teruji kebenarannya dan melalui suatu rangkaian dalam metode ilmiah. Pendidikan IPA di sekolah dasar bermanfaat bagi siswa untuk mempelajari diri sendiri dan alam sekitar. Pendidikan IPA menekankan pada pemberian pengalaman secara langsung untuk mengembangkan kompetensi agar siswa mampu menjelajahi dan memahami alam sekitar secara ilmiah. Pendidikan IPA diarahkan untuk "mencari tahu" dan "berbuat", sehingga bisa membantu siswa memperoleh pemahaman yang lebih mendalam tentang alam sekitar.

Melalui kegiatan pembelajaran IPA akan dibentuk karakter siswa untuk peduli dengan dirinya sendiri, temannya, dan lingkungan sekitarnya. Karakter yang dimaksut adalah sikap empati yang ada pada diri siswa, karena sikap empatai adalah kemampuan atau karakter yang merupakan bagian dari kepribadian individu dalam memahami perasaan dan pikiran orang lain (melibatkan proses efektif dan koknitif) (Gustini, 2017), sehingga pembelajaran IPA memberikan kesadaran dan pengetahuan kepada setiap peserta didik agar melakukan tindakatindakan yang baik yang tidak menyakiti diri sendiri dan orang lain.

\section{Sikap Empati}

Gusti Yuli (2010) menyatakan empati sebagai kemampuan menempatkan diri pada posisi orang lain sehingga orang lain seakanakan menjadi bagian dalam diri. Lebih lanjut 
dijelaskan oleh Baron dan Byrne (2005: 111) yang menyatakan bahwa empati merupakan kemampuan untuk merasakan keadaan emosional orang lain, merasa simpatik dan mencoba menyelesaikan masalah, dan mengambil perspektif orang lain. Arwani (2002: 56) menyatakan empati terhadap pasien merupakan perasaan dan "pemahaman" dan "penerimaan" perawat terhadap pasien mengenai apa yang dialami pasien dan kemampuan merasakan "dunia pribadi pasien". Empati merupakan sesuatu yang jujur, sensitive dan tidak dibuat-buat didasarkan atas apa yang dialami orang lain.

Berdasarkan berbagai uraian tersebut dapat disimpulkan bahwa empati merupakan kemampuan yang dimiliki individu untuk mengerti dan menghargai perasaan orang lain dengan cara memahami perasaan dan emosi orang lain serta memandang situasi dari sudut pandang orang lain.

Namun kenyataan dilapangan menunjukan bahwa sejak dibelakukanya kurikulum 2013 sampai denga sekarang 2018, proses pembelajaran belum dapat membentuk karakter siswa terutama sikap empati sepenhnya dan hasil belajar peserta didik pada tema 1 tidak mengalami peningkatan yang drastis, hal tersebut dirasakan oleh sekolah-sekolah yang telah menerapkan kurikulum 2013.

Data di atas didikung dengan fenomena sosial menunjukkan bahwa perilaku empati peserta didik di Indonesia menurun. Siswa cenderung bersikap individualistis, lunturnya nilai-nilai luhur kemanusiaan dan kemasyarakatan dari kehidupan, seperti tolong-menolong, kekeluargaan, kerjasama, kebersamaan, dan kepedulian kepada orang lain. Peserta didik cenderung egois atau memikirkan kepentingan sendiri tanpa menghiraukan kepentingan bersama (Gustini, 2017), hal tersebut dapat dilihat anak-anak SD yang sering berkelahi atau tauran dengan teman-teman sebayanya, dan bermain game online.

Berdasarkan hasil observasi yang dilaksanakan di SDN 20 Kurao Pagang pada hari senin, 05 Novmber 2018 penulis menemukan bawa selama pembelajaran siswa sering mengangu temannya, mendorong-dorong kursi temannya, mentertawakan temannya saat mengemukakan pendapat, saat istirahat peserta didik saling dorong-dorongan, menendang kaki temannya sampai temannya terjatuh, dan mentertawakan temanya yang pendiam, berdasarkan pengamatan penulis dapat menyatkan bahwa apa yang terjadi menunjukan proses pembelajaran yang diaksanakan masih dalam bentuk konseptual, karena pada awal proses pembelajaran siswa telah mempelajari tentang organ gerak manusia sehingga peserta didik seharusnya paham dengan apa dampak terhadap tindakan-tindakan yang mereka lakukan seperti yang disampaikan di atas, menunjukan peserta didik tidak dapat 
menjadikan pembelajaran tersebut sebagai karakter atau sikap dalam kehidupan sehariharinya.

Selain itu penulis juga melakukan pengamatan terhadap hasil belajar siswa kelas V SDN 20 Kurao Pagang, diperoleh bahwa hasil belajar peserta didik pada tema 1 tentang organ gerak manusia dan hewan diperolehlah nilai peserta didik sebagai berikut:

Tabel 1.

Nilai Rata-Rata siswa kelas V SDN 20 Kurao Pagang Pada Tema Organ Gerak Manusia dan Hewan

\begin{tabular}{|c|c|c|c|c|c|c|}
\hline \multirow{2}{*}{ No } & \multirow{2}{*}{ Kelas } & Jumlah & \multicolumn{2}{|c|}{ Siswa yang Tuntas } & \multicolumn{2}{c|}{ Siswa yang Belum Tuntas } \\
\cline { 4 - 7 } & & Siswa & Jumlah & Persentase & Jumlah & Persentase \\
\hline 1 & IVA & 26 & 12 & $46 \%$ & 14 & $54 \%$ \\
\hline 2 & IVB & 26 & 10 & $38 \%$ & 16 & $62 \%$ \\
\hline
\end{tabular}

Tabel 1, menunjukan bahwa hasil belajar IPA dengan tema organ gerak pada manusia dan hewan, diaman hasil belajar siswa adalah pada kelas A yang terdiri dari 26 peserta didik, peserta didik yang tuntas sebanyak 12 orang (46\%) dan siswa yang belum tuntas sebanyak 14 orang (54\%), kemudian pada kelas B dengan jumlah siswa 26 orang jumlah siswaa yang tuntas terdiri dari 10 (38\%), dan siswa yang belum tuntas berjumlah 16 orang (62\%).

\section{Hasil Belajar}

Menurut pendapat Nawawi (dalam Susanto, 2013), menyatakan bahwa "Hasil belajar dapat diartikan sebagai tiket keberhasilan siswa dalam mempelajari materi pelajaran di sekolah yang dinyatakan dalam skor yang diperoleh dari hasil tes mengenal sejumlah materi pelajaran tertentu". Menurut Mulyono (2001 : 26), aktivitas artinya kegiatan/ keaktifan. Jadi segala sesuatu yang dilakukan atau kegiatankegiatan yang terjadi baik fisik maupun nonfisik, merupakan suatu aktivitas. Belajar menurut Hamalik (2001 : 28), adalah suatu proses perubahan tingkah laku individu melalui interaksi dengan lingkungan. Sedangkah Sudirman (2003 : 22) menyatakan : Belajar sebagai suatu proses interaksi antara diri manusia dengan lingkungannya yang mungkin berwujud pribadi, fakta, konsep, ataupun teori. Jadi peniliti berkesimpulan bahwa aktivitas belajar adalah segala kegiatan yang dilakukan dalam proses interaksi (guru dan siswa) dalam rangka mencapai tujuan belajar.

Berdasarkan pendapat tersebut, maka hasil belajar dapat diartikan sebagai perubahan yang dialami individu atau 
kelompok, akibat dari pengaruh faktor internal dan eksternal, sebagai akibat dari proses pengalaman yang disadari dalam sebuah kegiatan, yang menampilkan hasil perubahan baik dalam bentuk pengetahuan, sikap, dan keterampilan yang dimiliki.

Berdasarkan masalah tersebut dibutuhkanlah penanganan dalam perbaikan sikap dan hasil belajar peserta didik agar pembelajaran IPA yang dipelajari dapat mendukung pertumhan peserta didik, untuk dapat memiliki sikap empati dan hasil belajar yang baik, karen Pendidikan IPA menekankan pada pemberian pengalaman secara langsung untuk mengembangkan kompetensi agar siswa mampu menjelajahi dan memahami alam sekitar secara ilmiah, salah satu model yang sesuai dan dapat mengatasi permasalahan tersebud adalah model role plyaing, yang menurut Depdikbut (dalam Aina Mulyana, 2012) role playing adalah salah satu bentuk permainan pendidikan yang digunakan untuk menjelaskan perasaan, sikap, tingkah laku dan nilai, dengan tujuan untuk menghayati perasaan, sudut padang dan cara berfikir orang laian.

\section{Model Role Playing}

Role playing merupakan berakting sesuai dengan peran yang telah ditentukan terlebih dahulu. Menurut Sudjana (2009) model role playing adalah suatu cara mengajar dengan jalan mendramatisaikan bentuk tingkah laku dalam hubungan sosial.
Role playing merupakan salah satu jenis model pembelajaran yang bersifat komplek. Blatner (dalam Komalasari, 2010: 58) model pembelajaran role playing mengeksplorasi situasi sosial yang komplek, yang menekankan pada keterlibatan emosional dan alat indra ke dalam situasi masalah yang dihadapi. Model role playing merupakan suatu cara penguasaan bahanbahan pelajaran melalui pengembangan imajinasi dan penghayatan siswa. Pengembangan imajinasi dan penghayatan dilakukan siswa dengan memerankannya sebagai tokoh hidup atau benda mati. Permainan ini pada umumnya dilakukan lebih dari satu orang, hal itu bergantung kepada yang diperankan.

Berdasarkan beberapa pendapat di atas, maka dapat disimpulkan bahwa model pembelajaran role $p l$ aying merupakan jenis model pembelajaran yang aktif dan menyenangkan. Penerapan model pembelajaran role playing dapat meningkatkan motivasi dengan memainkan peran tokohtokoh yang ada dalam hubungan sosial, sehingga siswa dapat melibatkan keterampilan emosional sebagai orang lain di luar dirinya.

Berdasarkan permasalahan tersebut, maka penulis melakukan study kasus dengan judul "Model pembelajaran Role Playing, sikap empati dan pembelajaran tematik terpadu di sekolah dasar". 


\section{KESIMPULAN}

Berdasarkan pembahasan dan kajian tori di atas maka dapat dijelaskan bahwa model Role Playing secara teroritis berdampak secara positif terhadap sikap empati dan hasil belajat siswa sekolah dasar dengan tema organ gerak manusia dan hewan.

Kajian teori ini di dasari oleh pengertian dan langkah-langkah pembelajar dengan menerapkan model Role Playing, memberikan kesempatan kepada setiap siswa untuk merasakan melalui peran yang mereka lakukan, siswa secara bergantian merasakan apa yang terjadi dan dampak baik dan buruk dari kegiatan yang dilakukan oleh siswa tersebut terutma yang berhubungan tentang organ gerak manusia dan hewan.

Salah satu peran yang di berikan kepada siswa agar mereka memiliki sikap empati baik kepada manusia dan hewan adalah dengan membagi peran pada siswa ada yang menjadi anak yang nakal yang selalu mengerjai temannya, salah satunya adalah melakukan tindakan yang menyebabkan timbulnya gerakan-gerakan yang berbahaya bagi organ gerak teman dan binatang disekelilingnya, dan peran siswa yang baik serta siswa yang selalu di perlakukan tidak baik oleh temanya tersebut, karena menurut Kohut (dalam Firman, 2018), melihat empati sebagai suatu keadaan atau proses yang menunjukan bahwa seseorang merasa bahwa dia berada pada posisi orang lain itu.

Pelaksanaan peran tersebut berdarkan kajian yang dilakukan akan mampu membentuk sikap empati siswa karena dalam melakukan pementasan peran di depan kelas, maka siswa akan sendirinya akan memahami tindakan mereka.

Melalui pemahaman tersebut siswa secara tidak langsung akan menyadari bagai mana jika dirinya diperlakukan demikian, maka akan menyebabkan beberapa organ geraknya akan mengalami cidra, begitujuga jika dia melalukan hal tersebut terhadap hewan yang ada di sekelilingnya.

Timbulnya kesadaran dalam diri siswa akan memberikan pengetahuan yang lebih kuat daripada siswa hanya mempelajarinya secara teoritis saja, model Role Playing menyajikan proses pembelajaran yang bersumber pada melakukan, menemukan, dan menuliskan kesimpulan dari kegiatan pembelajaran yang dilakukan.

Berdarakan tiga langkah pengetahuan yang dialami siswa dalam proses pembelajaran tersebut, akan membuat siswa lebih memahami materi yang ada terutama tentang organ gerak manusia dan hewan.

Berdampak secara positif pada pemebelajaran tematik terpadu yang dilaksanakan, karena seperti penjelasan di atas yang menyatakan bahwa model Role Playing memberikan kesmpatan siswa untuk memeran berarti siswa melakukan/terlibat 
langsung dalam pembelajaran, siswa lain, berpartisipasi dalam pergaulan, menemukan hal-hal yang berubungan menunjukkan minat, dan menunjukkan dengan apa yang dimaksut dengan organ kepuasan dalam beraktivitas. gerak dan apa dampak baik dan buruknya, terhadap manusia dan hewan, dan siswa pada akhir pembelajaran diberikan kesempatan untuk menyimpulkan kegiatan pembelajaran yang telah dilakukan, sehingga memantapkan pemahaman siswa pada materi yang dibelajari tersebut.

Pada kajian teori diatas menunjukan bahwa model Role Playing dapat dijadikan sebagai salah satu solusi dalam membentuk sikap empati dan hasil belajar siswa sekolah dasar kelas $\mathrm{V}$ terutama pada tema 1 tentang organ gerak manusia dan hewan.

Pada hakikatnya setiap siswa memiliki sikap empati dalam drinya, namun yang harus menjadi perhatian bagi seorang pendidik adalah bagai mana usaha untuk mengembankan sikap empati tersebut menjadi tindakan dan kebiasaan kepada sorang siswa karena dalam pendidikan, membentuk dan mengubah sikap anak menjadi lebih baik adalah tujuan utama, terutama sikap empati yang menjadikan seseorang mampu menjaga hubungan anatara sesama, karena Schneiders (dalam Imalatul Khaira. Firman. Nelviyarni S, 2017) menjelaskan, penyesuaian sosial merupakan cara yang dilakukan individu dalam menyelaraskan kebutuhan internal dengan kebutuhan eksternal yang tercermin dalam kemampuan menjalin relasi dengan orang menerapkan model Role Playing maka akan membentuk sikap empati dan berdampak secara positif pada pembelajaran IPA tema organ gerak manusia dan hewan, karena siswa tidak sekedar mendengar tapi di melakukan dan menemukan hal-hal yang berkaitan dengan pembelajaran pada hari itu.

Berdasarkan pembahasan di atas maka model Role Playing dapat disimpulkan sebagai model yang berdampak dampak baik terhadap pembentukan sikap empati dan hasil belajar terutama tema organ gerak manusia dan hewan pada kelas $\mathrm{V}$ sekolah dasar.

\section{DAFTAR PUTAKA}

Afifurrahman, L. H. S. (2015). Pengembangan Permainan Monopoli Panakawan dalam Pembelajaran Tematik Integratif Tema Pengalamanku untuk Kelas I Sekolah Dasar Negeri Temu II Kanor Bojonegoro. Mahasiswa Teknologi Pendidikan, 6(2252-3863), 1-7.

Ahmad sabri. (2007). Strategi Belajar Mengajar dan Micro Teacing. book, Bumi Aksara. Retrieved from https://books.google.co.id/books?id=Tg QBAgAACAAJ

Dyah Worowirastri E., Ima Wahyu P.U, D. I. K. (2018). Analisis Penggunaan Media Pembelajaran Tematik di SD Muhammadiyah 9 Kota Malang. Jurnal Indovasi Pembelajarano, 4(424600873), 17-25. 
Firman. (2018a). Efektifitas Layanan Penguasaan Konten Menggunakan Model Pembelajaran Role Playing Untuk Meningkatkan Kepercayaan Konselor | Jurnal Ilmiah Konseling. Ilmiah Ilmiah KOnseling, (November), $1-8$.

Firman. (2018b). Hubungan Empati dengan Agresivitas Siswa SMA Pertiwi 2 Padang Serta Hubungan Empati dengan Agresivitas Siswa SMA Pertiwi 2 Padang Serta Implikasinya dalam Bimbingan dan Konseling. Neo Konseling, (November), 1-7. https://doi.org/10.24036/XXXXXXXX XX-X-XX

Gusti Yuli, A. M. M. S. (2010). KEMATANGAN EMOSI. Psikologi Universitas Mulia Kudus, I(1), 33-42.

Gustini, N. (2017). Empati Kultural Pada Mahasiswa. Journal of Multicultural Studies in Guidance and Counseling, 1(1), 17-35.

Imalatul Khaira. Firman. Nelviyarni S. (2017). Efektivitas Pendekatan Rational Emotive Behavior Therapy ( Rebt ) Dalam Meningkatkan Penyesuaian Sosial Anak Asuh Di Panti Asuhan Wira Lisna Padang Imalatul Khaira Firman Abstrak. Bikotetik, 1(1), 1-7.

Melka, F. D., Ahmad, Firman, Syukur, Y., Sukmawati, I., \& Gusri, P. (2017). Hubungan Kecerdasan Emosional dengan Penerimaan Teman Sebaya serta Implikasinya dalam Bimbingan dan Konseling. Neo Konseling, 0, 1-7. https://doi.org/10.24036/XXXXXXXX XX-X-XX

Novianto, A., \& Mustadi, A. (2015). Analisis Buku Teks Muatan Tematik Integratif, Scientific Approach, dan Authentic Assessment Sekolah Dasar. Jurnal Kependidikan, 45(1), 1-15.

Rusmawan, A. D. S. K. dan. (2015). Kendala Guru Sekolah Dasar Dalam Implementasi Kurikulum 2013.
Cakrawala Pendidikan, 3, 457-467.

Sudjana. (2009). Metode Statistik. book, Bumi Aksara. Retrieved from https://books.google.co.id/books?id=Tg QBAgAACAAJ

Sumarto. (2002). Faktor-Faktor Lingkungan Strategik Dalam Pengembangan Perguruan Tinggi SwastaStudi Tentang Faktor-Faktor Lingkungan Perguruan Tinggi Swasta Yang Terakreditasi Di Jawa Barat. book, Bumi Aksara. Retrieved from https://books.google.co.id/books?id=Tg qbagaacaaj

Susanto, A. (2013). Teori Belajar dan Pembelajaran di Sekolah Dasar. book, Bumi Aksara. Retrieved from https://books.google.co.id/books?id=Tg qbagaacaaj

Trianto. (2007). Model Pembelajaran Terpadu Dalam Teori dan Praktek. book, Bumi Aksara. Retrieved from https://books.google.co.id/books?id=Tg qbagaacaaj

Uno, B. Hamzah dan Mohammad, N. (2015). Belajar Dengan Pendekatan Paikem: Pembelajaran, Aktif, Inovatif, Iingkungan, Kreatif, Menarik. book, Bumi Aksara. Retrieved from https://books.google.co.id/books?id=Tg QBAgAACAAJ

Warsiti. (2003). Pembentukan Karakter Siswa Sekolah Dasar Melalui Pembelajaran IPA. Seminar Nasional VII Pendidikan Biologi, 384-387. 